Chirurgia (2019) 114: 359-368

No. 3, May - June

Copyright $\odot$ Celsius

http://dx.doi.org/10.21614/chirurgia.114.3.359

\title{
The Role of Laparoscopy in Abdominal Trauma: A 10-Year Review
}

\author{
Alexandru Eugen Nicolau', Marius Craciun², Raluca Vasile', Ahmad Kitkani³ ${ }^{3}$ Mircea Beuran ${ }^{1}$ \\ ${ }^{1}$ Clinical Emergency Hospital, Bucharest, Romania \\ ${ }^{2}$ Royal Liverpool and Broadgreen University Hospitals NHS Trust, Liverpool, UK \\ ${ }^{3}$ General Hospital Rotthalmünster, Rotthalmünster, Germany
}

Corresponding author: Alexandru Eugen Nicolau, MD, PhD

Clinical Emergency Hospital

Bucharest, Romania

E-mail: aenicolau@gmail.com
Received: 13.06 .2018 Accepted: 20.08 .2018

\section{Rezumat}

Rolul laparoscopiei în traumatismele abdominale: o evaluare pe 10 ani

Laparoscopia este acceptată în plăgile abdominale (PA), dar în contuziile abdominale (CA) utilizarea ei este controversată. Lucrarea noastra evalueaza utilizarea laparoscopiei diagnostice (LD) si al laparoscopiei terapeutice (LT) in traumatismele abdominale în perioada Decembrie 2006 - Ianuarie 2016. S-au analizat indicatiile, leziunile, LT, conversiile, complicațiile, durata spitalizarii. LD s-a efectuat la 49 de pacienți stabili hemodinamic, 42 de barbați şi 7 femei cu varsta medie $36,6 \pm 13,3$ ani. Au fost 20 PA SI 29 CA. Principalele indicații au fost: diagnosticul penetrației în PA, suspiciunea de leziune de organ cavitar sau diafragm, hemoragia activă în leziunile viscerale din CA. Preoperator, 11/48 ecografii abdominale şi 4/28 examene CT au fost fals negative. Dintre cele 20 LD pentru PA, 3 au fost negative si 4 nonterapetice. Au fost 4 LT şi 7 conversii. La cele 29 de CA, principalele leziuni au fost: perforație de organ cavitar 9, dilacerări mezenterice 6, leziuni splenice 2, leziuni de diafragm 2. Au fost $10 \mathrm{LT}$ şi 9 conversii si 14 LT: enterorafii şi enterectomii 6 (5 asistate), frenorafii 4, colecistectomie 1, hemostaze 4. Durata intervențiilor şi spitalizarea postoperatorie au fost mai mari în conversii. Au fost 6 complicații şi 3 decese. $\mathrm{Nu}$ au fost leziuni omise. O laparotomie nenecesară s-a evitat în 18/49 cazuri (36,73\%). În cazuri selectate de PA şi CA cu diagnostic clinic şi imagistic echivoc, laparoscopia este o modalitate diagnostica utilă, cu potențial terapeutic, care reduce laparotomiile nenecesare, perioada de spitalizare şi complicațiile. 
Cuvinte cheie: plagi abdominale, contuzii abdominale, laparoscopie

\begin{abstract}
Laparoscopy is accepted in penetrating abdominal trauma (PAT), but its role in blunt trauma (BAT) remains a controversial one. Our study assessed the utility of diagnostic laparoscopy (DL) and therapeutic laparoscopy (TL) in abdominal trauma between December 2006 and January 2016. We analysed the indication for laparoscopy, type of lesions, TL, conversion rate, complications and length of hospital stay. 49 patients had a DL: 42 males and 7 females, with a mean age of $36.1 \pm 13.3$. We had 20 PAT and 30BAT. The indications for laparoscopy were: diagnosis of penetration in PAT, suspicion of hollow organ injury or diaphragm injury, active bleeding in organ injuries in BAT. 11/48 of preoperative ultrasounds and 4/48 of CT's were false negative. In 3 of 20 PAT, DL was negative and in 4 nontherapeutic. There were 4 TL's and 7 conversions. The main injuries in BAT were: 9 hollow organ perforations, 6 mesenteric lacerations, 2 diaphragmatic and 2 splenic injuries. There were 10 TL's, 9 conversions and $14 \mathrm{TL}$. The operative time and length of hospital stay was higher in the conversion group. There were 6 complications and 3 mortalities. There were no missed injuries. An unnecessary laparotomy was avoided in 18/49 cases (36.73\%). In selected cases of PAT and BAT with equivocal clinical and imaging diagnosis, laparoscopy is a useful tool with therapeutic role, that reduces unnecessary laparotomies, complication rate and hospital stay.
\end{abstract}

Key words: Penetrating abdominal trauma, blunt abdominal trauma, laparoscopy

\section{Introduction}

Laparoscopy has been used as a diagnostic tool in abdominal trauma (AT) for more than six decades. However, it is not largely used, and its role is relatively limited, especially in blunt abdominal trauma (BAT).

Laparoscopy is a diagnostic but also therapeutic minimally invasive tool, efficient and safe in selected patients when it is performed by surgeons with laparoscopy and emergency surgery experience in trauma centres $(1,2)$. Laparoscopy is accepted and recommended in selected cases of abdominal and thoracoabdominal stab wounds for diagnosis of diaphragmatic injuries $(2,3,4)$. The actual benefit of DL in abdominal trauma is still under review. Compared to other diagnostic tools, laparoscopy is also therapeutic having all the advantages of minimally invasive interventions. The role of laparoscopy in AT is still to be determined.

In this article we present our experience using laparoscopy in AT, where it has an established role in stab abdominal trauma (PAT), but which is still a subject of debate in BAT, where its role has been neglected. Establishing an early diagnosis in AT with early resuscitation and correct management, especially in equivocal cases, is essential in decreasing morbidity and mortality. Specifically, laparoscopy can reduce the number of unnecessary laparotomies and their complications, reduce hospital stay and patient recovery time and finally decrease hospital costs which are high in trauma centres $(2,4)$.

\section{Material and Methods}

We performed a retrospective analysis of all the AT cases that were managed laparoscopically in our unit between January 2006 and December 2016. We identified and analysed the mechanism of injury, the Injury Severity Score (ISS), ultrasound and computer tomography (CT) findings, the indication of laparoscopy, injuries identified, the procedure performed and the cause of conversion to open surgery. 
Also, we looked at the operative time, length of hospital stay, including time spent in intensive care, post-operative complications and mortality.

Patient selection for DL was essential. In case of BAT, DL was performed after CT abdomen with contrast and abdominal ultrasound. In case of a stab wound, the main indication for DL was to identify organ injury; this was performed after clinical examination, wound exploration, ultrasound and in some cases after CT.

The decision for DL, therapeutic laparoscopy (TL), laparotomy or conversion to open surgery was made by the operating surgeon. The indications for DL were:

- equivocal clinical examination with free intraabdominal fluid and without solid organ injury (SOI) on ultrasound and / or $\mathrm{CT}$, which raised the suspicion of hollow organ injury (HOI) and / or mesenteric injury;

- patients admitted to intensive care with multiple injuries with no signs of improvement and equivocal clinical examination, where the $\mathrm{CT}$ raised the possibility of organ injury, 'unclear abdomen' (5);

- patients with multiple injuries, with equivocal clinical and imagistic examination, that required a general anaesthetic for non-abdominal surgery where there was suspicion of HOI and / or diaphragm injury (6).

The exclusion criteria for DL were:

- haemodynamically unstable patients; diagnostic laparoscopy was performed only in stable patients (pre and during surgery) with a systolic blood pressure $>90 \mathrm{mmHg}$ and heart rate of less than 120 beats per minute;

- patients with head injuries and GCS less than 12 ;

- patients with decompensated heart, lung or liver disease;

- patients with an immediate indication for laparotomy, major haemorrhage, organ evisceration, multiple major injuries;
- scarred abdomen.

DL was performed under general anaesthetic in supine position. The surgeon was positioned on the right side of the patient. The pneumoperitoneum was performed 'closed', using a Veress needle or using the 'open technique'. A 10 $\mathrm{mm}$ port was placed sub-umbilical for a $30^{-}$ degree telescope and we used a starting pressure of $\max 8 \mathrm{~mm} \mathrm{Hg}$ where a diaphragmatic lesion was suspected and, once this was ruled out, the pressure was increased to $12 \mathrm{~mm} \mathrm{Hg}$. We used 2 working ports, of $5 \mathrm{~mm}$ and $10 \mathrm{~mm}$, placed either on the midline sub-umbilical and supraumbilical or para-umbilical on the left and right midclavicular line, depending on the operating surgeon's preference (Fig. 1). Firstly, a washout of the peritoneal cavity was performed, after which the diaphragm, spleen, stomach, liver, omentum and the transvers colon were inspected. Then, the patient was placed in the Trendelenburg position and after the Treitz ligament was identified, the small bowel was inspected down to the caecum, which is an essential manoeuvre to identify lesions (Fig. 2). By tilting the operating table to the left or right, or head up or head down, the ascending and descending colon, hepatic and splenic flexure and rectum were inspected.

DL was considered negative in the absence of lesions, and non-therapeutic where the lesions identified did not warrant a surgical intervention. Therapeutic laparoscopy (TL) was defined as the intervention were the identified

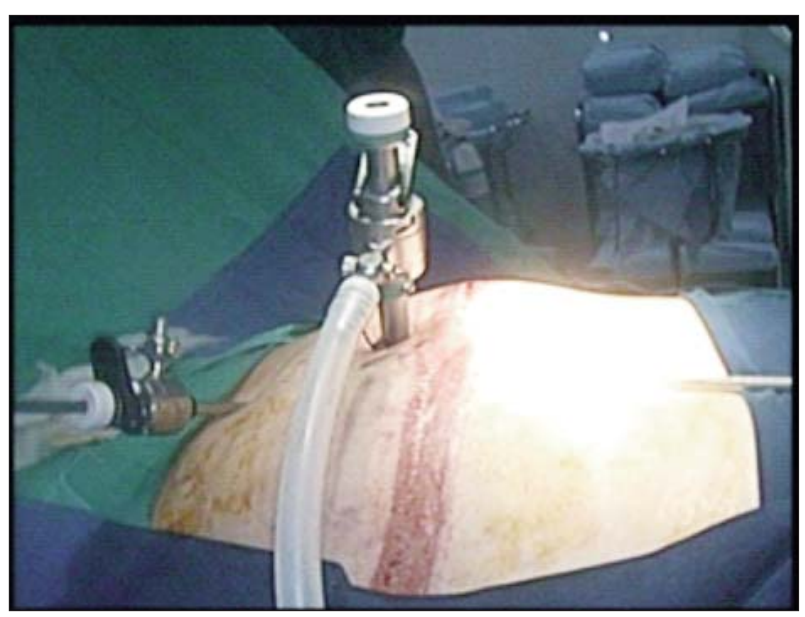

Figure 1. Trocar position on midline 


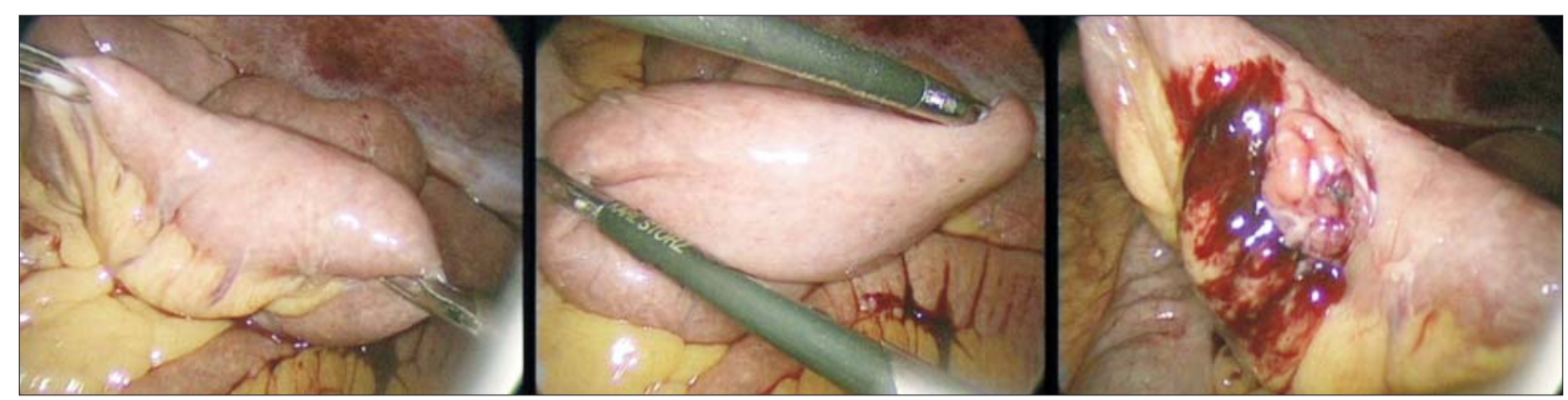

Figure 2. Small bowel inspection and bowel perforation

lesions were treated totally laparoscopic or assisted laparoscopic. In case of perforated hollow viscus identified laparoscopically, a washout of the peritoneal cavity was performed, followed by enterotomy under direct vision through a 5-6 $\mathrm{cm}$ transverse incision extended laterally from the first $10 \mathrm{~mm}$ port (Fig. 3) (7).

\section{Results}

During the 10-year period, 774 patients with AT had surgery: 658 for BAT and 126 for PAT. 49 out of $774(6.33 \%)$ haemodynamically stable patients were treated laparoscopically, out of which 29 (4.5\%) had BAT and 20 (15.07\%) had PAT. There were 7 women and 42 men with a mean age of $36.6 \pm 13.3$ (range 20-76). The mean ISS for AT was $15.04 \pm 10.293$, the mean ISS for BAT was 20.366 \pm 9.535 and for PAT $6.631 \pm 3.759$. The causes of injuries are presented in Table 1. The laparoscopic procedures
Table 1. Aetiology

\begin{tabular}{lcc}
\hline Cause & PAT & BAT \\
\hline Road traffic accident & & 20 \\
\hline Accidental fall & 2 & 5 \\
\hline Injury at work & 1 & \\
\hline Assault & 17 & 4 \\
\hline Overall & 20 & 29 \\
\hline
\end{tabular}

were performed by 12 surgeons, 3 of them having vast experience in laparoscopic surgery; the mean number of procedures was 4 per surgeon (range 1-15), 6 of them having performed only one procedure.

There were 19 penetrating injuries and 1 gunshot wound with a metallic fragment (Fig. 4). With regards to locations, 5 were thoraco-abdominal, 5 epigastric, 6 in the left upper quadrant and left flank, 2 sub-umbilical, 1 in the upper quadrant and 1 scrotal. In 3 cases, the injuries were self-inflicted. All patients had an ultrasound pre-operative and 2

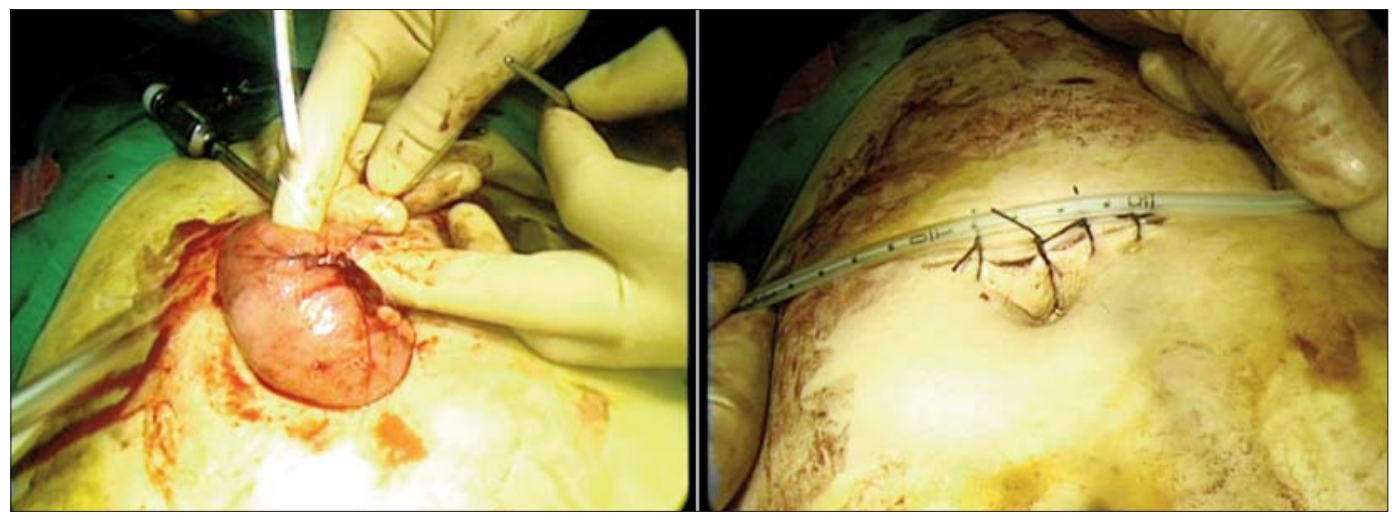

Figure 3. Mini laparotomy with enterorrhaphy 


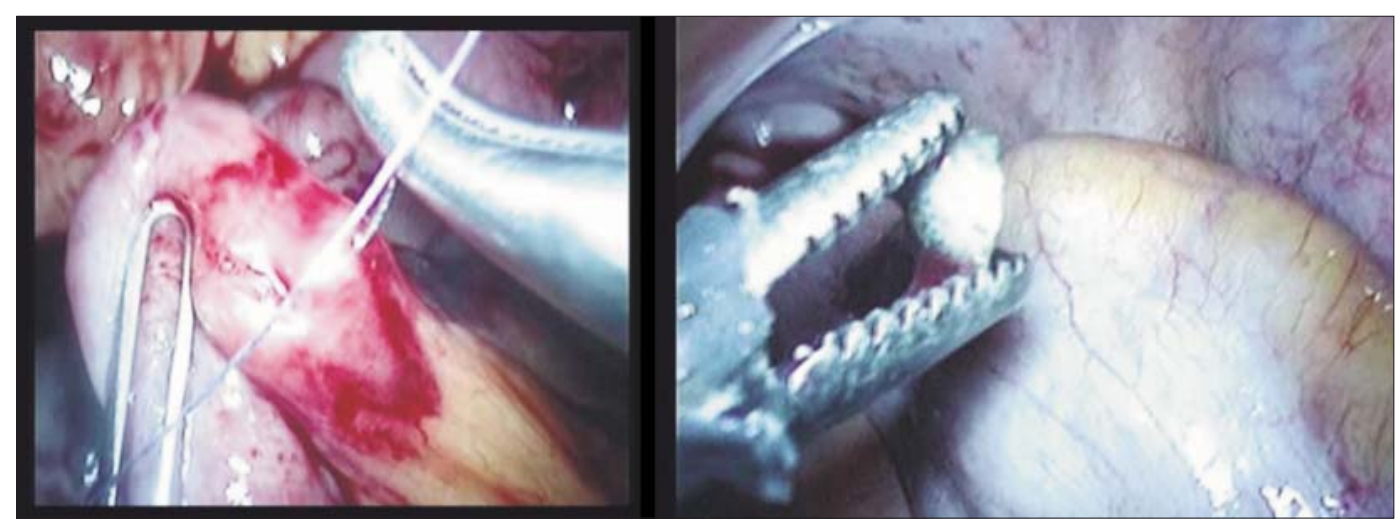

Figure 4. Enterorrhaphy of injury caused by a metallic fragment

Table 2. Imaging results

\begin{tabular}{lccccc}
\hline & \multicolumn{2}{c}{ PAT, $\mathbf{n = 2 0}$} & \multicolumn{2}{c}{ BAT, $\mathbf{n = 2 9}$} \\
\hline Imaging & US & CT & US & CT \\
\hline $\mathrm{n}$ & 19 & 2 & 28 & 26 \\
\hline False negative & $5(26.31 \%)$ & $1(50 \%)$ & $6(21.43 \%)$ & $3(11.53 \%)$ \\
\hline Missed lesions & $\begin{array}{l}\text { stab liver } \\
\text { injuries 2 }\end{array}$ & 1 diaphragm & small bowel & serforations 2 & small bowel \\
& diaphragm injuries 2 & & perforations 2 \\
& colon perforation 1 & diaphragmatic injury 2 & diaphragmatic injury 1 \\
\hdashline & & stab liver wound 1 & \\
\hline & & mesentery injury 1 & \\
\hline
\end{tabular}

had CT (Table 2). In 3 cases, the laparoscopy was negative (15.78\%) and in other 5 it was nontherapeutic (due to spontaneous haemostasis). TL was possible in 5 cases $(25 \%)$ and in 7 cases (35\%) a conversion to open was performed, out of which one laparotomy was unnecessary
(Table 3). The indications for conversion were: haemorrhagic liver injury in 2 cases, unable to identify the source of bleeding in 2 cases, colonic injury associated with other visceral injuries in 3 cases.

Regarding blunt injuries, 16 patients out of

Table 3. Abdominal wounds

\begin{tabular}{lcccc}
\hline Injury & $\mathbf{n}$ & DL & TL & Conversion \\
\hline Non-penetrating & 3 & 3 & \\
\hline No organ injuries & 4 & 3 & Frenoraphy 1 & \\
\hline Diaphragm & 1 & & Frenoraphy 2 & \\
\hline Diaphragm and spleen & 2 & & & Coloraphy 1 \\
\hline Colon & 1 & & Coloraphy and Splenectomy 1 \\
\hline Colon and spleen & 1 & & Colectomy and Nephrectomy 1 \\
\hline Colon and kidney & 1 & & & Enterorrhaphy and Mesenterorrhapy 1 \\
\hline lleum & 1 & & Haemostasis 1 & \\
\hline Jejunum and mesentery & 1 & & & \\
\hline Stab liver injury & 3 & 1 & & \\
\hline Abdominal wall bleeding & 1 & & Haemostasis 1 and Packing 1 \\
\hline Omentum injury & 1 & 1 & & \\
\hline Overall & 20 & 8 & 5 & 7 \\
\hline
\end{tabular}


29 (55.17\%) had multiple injuries associated: 7 patients with only one area affected, 6 with two and 3 with three areas. 10 patients had associated thoracic trauma, 7 had head injuries, 3 had pelvic fractures and 3 had limb fractures. 28 patients had ultrasound and 26 had CT (Table 2). Based on clinical examination and imaging, 16 patients had a suspicion of HOI and 6 had free fluid intraperitoneally without SOI on CT, out of which 5 had bowel perforation. 9 patients with SOI had DL to assess for bleeding and possible associated HOI or mesenteric injury. In one case, DL was performed late: the patient had blunt liver injury, complicated with biliary leak, drained percutaneously, which prompted the DL that was negative. Tables 4 and 5 show the cases of SOI, diaphragm and HOI with the interventions performed.

In 8 cases $(27.59 \%)$, DL was performed after more than 24 hours from admission, for suspicion of SOI, for diaphragmatic injury confirmed on CT, for HOI and mesentery injury and for 'unclear abdomen' (Table 6). One patient had a negative laparoscopy and in 9 patients $(31.03 \%)$ the laparoscopy was nontherapeutic. TL was possible in 10 patients $(34.48 \%)$, out of which 4 were enterotomies assisted laparoscopically and one was a bowel resection assisted laparoscopically. 9 patients needed conversion to open (32.65\%), out of which $2(12.5 \%)$ were deemed unnecessary

Table 4. Suspicion of $\mathrm{HOI}$

\begin{tabular}{|c|c|c|c|c|}
\hline Injury & $\mathbf{n}$ & DL & TL & Conversion \\
\hline Negative & 1 & 1 & & \\
\hline Bowel perforation & 8 & & $\begin{array}{l}\text { Assisted } \\
\text { laparoscopically } 5\end{array}$ & Enterectomy 2, Enterorrhaphy 1 \\
\hline Mesentery avulsion & 6 & 2 & Haemostasis 1 & Enterectomy 1 , Mesenterorrhaphy 2 \\
\hline Abdominal wall haematoma & 1 & & Haemostasis 1 & \\
\hline Gall bladder avulsion & 1 & & Cholecystectomy 1 & \\
\hline Duodenal injury suspicion & 1 & & & Drainage 1 \\
\hline Overall & 18 & 3 & 8 & 7 \\
\hline
\end{tabular}

Table 5. Solid organ injury and diaphragm

\begin{tabular}{|c|c|c|c|c|}
\hline Injury & $\mathrm{n}$ & DL & TL & Conversion \\
\hline Splenic injury & 3 & 2 & & splenectomy 1 \\
\hline Stab liver injury & 2 & 1 & haemostasis 1 & \\
\hline Blunt liver injury & 3 & 3 & & \\
\hline Diaphragmatic injury & 2 & & frenoraphy 1 & frenoraphy 1 \\
\hline Drained biliary leak & 1 & 1 & & \\
\hline Overall & 11 & 7 & 2 & 2 \\
\hline
\end{tabular}

Table 6. BAT operated over $24 \mathrm{~h}$ from admission; * patients transferred from another hospital

\begin{tabular}{lll}
\hline $\begin{array}{l}\text { Admission } \\
- \text { surgery interval }\end{array}$ & Injuries & Operation \\
\hline $24 \mathrm{~h}^{*}$ & Small bowel perforation, peritonitis & \\
\hline $48 \mathrm{~h}^{*}$ & Duodenal contusion, post splenectomy, intubated & Conversion and wash out \\
\hline $48 \mathrm{~h}$ & Omentum avulsion, hemoperitoneum & Conversion and haemostasis \\
\hline $72 \mathrm{~h}$ & Abdominal wall haematoma & $\mathrm{DL}$ and drainage \\
\hline 4 days & Diaphragmatic rupture & TL and frenoraphy \\
\hline 7 days & Mesentery blunt injury, splenic injury grade I & DL and drainage \\
\hline 13 days & Biliary leak drained percutaneously & DL and drainage \\
\hline
\end{tabular}


(duodenal concussion). The indications for conversions were: omentum and mesentery avulsion with active bleeding in 4 cases, bowel ischaemia in one case, bowel perforations in 2 cases, active bleeding from splenic and liver avulsion, respectively, duodenal contusion with wall haematoma.

Overall, an unnecessary laparotomy was avoided in 18 out of 49 patients (36.73\%): 8 in PAT group and 10 in BAT group. TL was possible for $15 / 49$ patients $(30.61 \%)$ and there were $16 / 49$ conversions (32.65\%), out of which 3 were deemed unnecessary. 8/18 laparoscopies performed by surgeons with advanced experience in laparoscopic surgery needed conversion compared to $8 / 31$ performed by less experienced surgeons, however this was not statistically significant $(\mathrm{p}=0.179)$. Regarding TL, 9 were performed by surgeons with advanced laparoscopic skills and 6 by less experienced surgeons $(\mathrm{p}=0.11)$.

The operative time and length of hospital stay including intensive care was reduced for laparoscopy compared to conversions. However, the extent of injury was higher in the latter (Table 7). The length of hospital stay for patients with PAT was shorter compared to those with BAT.

6 patients developed post op complications $(12.24 \%)$ and there were $2(4.08 \%)$ mortalities due to multiple organ failure. 2 patients, out of the 33 that had a DL or TL, developed complications: one abdominal wall abscess with delayed bowel injury that required bowel resection and one death due to multiple organ failure, in a patient with gallbladder perforation and severe lung concussion. Out of the 16 patients that needed conversion, 4 had postoperative complications: 3 wound infections and one death due to multiple organ failure in an intravenous drug user, HIV positive with stab injury to the liver (self-inflicted) that required re-operation for packing.

\section{Discussion}

Laparoscopy in trauma is still under debate. Most articles published in literature have a small number of patients and are the work of enthusiastic surgeons with experience in laparoscopy and trauma. Unfortunately, there are not many published articles on this subject, especially in BAT (8). In trauma, the main role of laparoscopy is to establish the presence or absence of lesions that require laparotomy or observation, possibly a TL. However, the therapeutic role of laparoscopy is a secondary one, as it is dependent on the surgeon's experience, the extent of injuries and local resources (9). Exploratory laparotomy remains the gold standard in abdominal trauma. However, unnecessary laparotomies (negative and non-therapeutic), missed lesions or late diagnosis increases morbidity, mortality and the cost associated with abdominal trauma (10).

Although the incidence of unnecessary laparotomies has decrease due to improvements in imaging, they are still present in trauma centres, with $3.6 \%$ negative laparotomies, more frequent in stab injuries, and 6-27\% nontherapeutic laparotomies, with complication rates up to $14.5 \%$ and $12 \%$ respectively. For BAT, the incidence of non-therapeutic laparotomies in Europe reaches 27\% (11-14).

Missed injuries in AT have an incidence of $1.3-4 \%$ in recent publications, with complication rates of $14-27 \%$. Bowel injuries are the most common, the trauma surgeon's 'nightmare', especially nowadays, when the conservative, non-operative approach is preferred in AT $(12,15)$. Missed injuries are also the result

Table 7. Operative time and length of hospital stay ( $\mathrm{Cl}$ confidence interval 95\%)

\begin{tabular}{lcccc}
\hline & \multicolumn{2}{c}{ Laparoscopies DL / TL } & \multicolumn{2}{c}{ Conversions } \\
\hline & PAT & BAT & PAT & BAT \\
\hline Operative time (min) & $74.5 \pm 41 ; \mathrm{Cl} 22.28$ & $101.98 \pm 67.41 ; \mathrm{Cl} 28.83$ & $136 \pm 93.63 ; \mathrm{Cl} 74.92$ & $151.15 \pm 52.01 ; \mathrm{Cl} 33.98$ \\
\hline Length of stay (days) & $3.7 \pm 2.36 ; \mathrm{Cl} 1.28$ & $16.9 \pm 14.31 ; \mathrm{Cl} 6.12$ & $6 \pm 1.41 ; \mathrm{Cl} 1.13$ & $13.4 \pm 12.62 ; \mathrm{Cl} 8.25$ \\
\hline
\end{tabular}


of false negative ultrasound and CT, like in our case series, bowel perforations and diaphragmatic injuries being the most com- $^{-}$ mon ones (16).

In a systematic review of 51 articles for PAT, DL was performed in 2,569 patients, with a $33.8 \%$ conversion rate and $3.2 \%$ missed injuries (17). Out of $1,129(43.95 \%)$ patients with a positive laparoscopy for injury, $13.8 \%$ benefited from TL. Overall, DL had a diagnostic accuracy of $50-100 \%$ and in 23 of 51 reviewed articles the accuracy was $100 \%$. Diagnostic laparoscopy can also be used as a screening tool, following which, identification of hemoperitoneum and lor presence of bowel content would require laparotomy, without the need for further exploration to identify the lesions, and is recommended to surgeons with less experience in emergency laparoscopy $(17,18)$. Like in our series, the most common procedure performed during laparoscopy is frenorrhaphy (Fig. 5)(17). In a systematic review that compares 1,604 laparoscopies to 1,758 laparotomies for PAT, there was a reduction in wound infection rates, chest infections, length of hospital stay and duration of surgery in favour of the first. Laparoscopy had a sensibility of $100 \%$ in most studies, $45.6 \%$ of patients avoiding an unnecessary laparotomy; it had a conversion rate of $37.6 \%$ and in only 2 cases there were missed lesions (19). In 2 recently published series, TL in PAT was possible in $22.6 \%$ of cases and $58.5 \%$ respectively, had $26.6 \%$ and $7 \%$ conver-

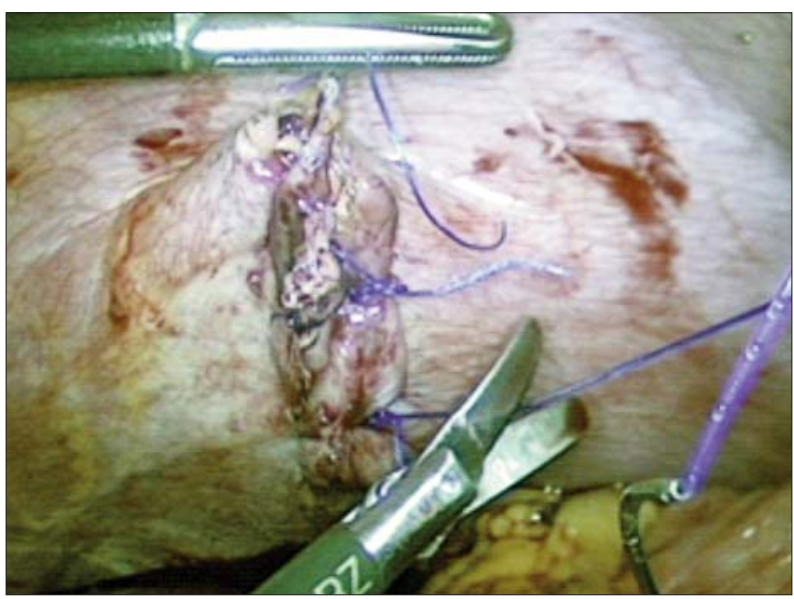

Figure 5. Frenorrhaphy sion rates; however, these were high volume centres $(20,21)$. In our series, laparotomy was avoided in $65 \%$ of cases and a TL was possible in $25 \%$ of cases with a conversion rate of $35 \%$.

In BAT, the number of patients that can benefit from laparoscopy is limited: unstable patients, with major blood loss and severe associated injuries are a contraindication for laparoscopy. Patients with SOI, that do not require an emergency laparotomy based on $\mathrm{CT}$, can be managed conservatively by close monitoring or embolization (22). CT is the gold standard examination for SOI and for identifying the source of bleeding with more than $90 \%$ accuracy, having an essential role in follow up also (23). In case of HOI and mesenteric injury, in the first 6 hours from the incident, CT can miss the injury in 5,9 -14.8\% of cases $(24,25,26)$. Free intraperitoneal fluid without SOI is the most common indirect sign present in more than $90 \%$ of bowel injuries (sensibility of over $90 \%$ but specificity below $33 \%)(23,24)$. HOI and mesenteric avulsion with bowel ischaemia, with or without major haemorrhage, are the most severe injuries. DL is superior to $\mathrm{CT}$ and ultrasound, offering a direct visualisation of the injury (27).

In our series, the main indications for diagnostic laparoscopy in BAT were: suspicion of HOI and mesentery injury, with or without diaphragmatic lesion, based on clinical examination, indirect signs on CT or no signs of improving whilst in intensive care, 'unclear abdomen' or suspicion of ongoing bleeding in SOI diagnosed on imaging. We had 8 cases of bowel perforation, where the ultrasound showed free intraabdominal fluids, apart from 3 cases, where it was false negative, while in one case the ultrasound showed a short segment of bowel with thickened wall. CT was performed in 6 of these cases and it was false negative in 2 of them (one CT was performed in another hospital). In the other 4 , there was free intraperitoneal fluid without SOI, 2 of the cases having bowel wall oedema and one case having mesentery avulsion.

In 7 patients DL was performed after more than 24 hours from admission for suspicion of HOI or diaphragm injury respectively, due to 
localised intraperitoneal fluid on imaging, non-improvement whilst in intensive care and equivocal or irrelevant clinical examination (sedated patients). In these cases of 'unclear abdomen', DL can offer a diagnosis and possibly lead to either a TL, like in our case, with frenorrhaphy and laparoscopic assisted bowel resection assisted, or either a therapeutic laparotomy for, in our case, mesenteric avulsion with active haemorrhage.

Patients that have inexplicable CT findings like free intraperitoneal fluid but without SOI can be monitored and treated expectantly. However, when the clinical examination is equivocal and there is a suspicion of hollow viscus injury, it is better for $\mathrm{DL}$ to be performed earlier, as it shortens the hospital stay and reduces the hospital costs (9). Two systematic reviews have shown the advantages of laparoscopy in AT, its diagnostic accuracy, with reduction in unnecessary laparotomies, morbidity and mortality $(8,17)$. In a multicentre study with 4755 DL for AT with $69 \%$ PATs, $19.3 \%$ were TL with $20.2 \%$ conversion rate and mortality of $1.8 \%$ not related to laparoscopy (4). In a meta-analysis, Cirocchi et al (28) compared 1991-2000 period and 2000-2010 period and showed that there is an increase use of laparoscopy in the latter period (1515 versus 5305 cases) with more TL $(7.2 \%$ vs $23.7 \%)$ and less need for conversions ( $41 \%$ vs $20.7 \%$ ). The overall mortality was $0^{-}$ $1.7 \%$. Bowel and diaphragmatic injuries were the ones that benefit the most from TL. In our cohort, $32,65 \%$ of the cases needed conversion. The main indications for conversion were: uncontrollable bleeding in 8 cases and small and large bowel injuries in 6 cases. A reason to be reserved regarding the use of diagnostic laparoscopy is the possibility of missing injuries, particularly HOI. In the first published papers on this subject in the 1990', missed injuries were reported in $40-77 \%$ of cases; back then, the surgeons were not familiar with laparoscopy, image quality was poor, and equipment and accessories had limited performance (18). In our case series there were no missed injuries; similar results were also reported by other authors $(14,20,29,30)$.
Specific complications are represented by iatrogenic vascular and visceral injuries, pneumothorax in case of diaphragmatic injury and the theoretical gas embolism that was not recorded at any patient with inferior vena cava injury managed laparoscopically (30-32). General complications of laparoscopy in abdominal trauma varies between 1 to $12.2 \%$ $(4,29,30,33)$. In our series, the complication rate was of $6.06 \%$ at those with diagnostic and therapeutic laparoscopy compared with $25 \%$ at those that required conversion to open surgery, however, the latter ones had more extensive lesions. There was one death in the laparoscopic group with no relation with laparoscopy. The indication and surgical technique were established by the operating surgeon, based on his experience in trauma laparoscopy but also in advanced laparoscopy, experience that varied between the 12 surgeons.

Unfortunately, only a small number of articles are published on this subject, with small number of patients, with no randomised trials required for implementation of general guidelines. Also, our residents lack of adequate training due to lack of such cases. We need prospective multicentre studies for a realistic evaluation of laparoscopy in trauma. Our study has its own limitations: is retrospective, with a small number of cases, like the majority in laparoscopy in abdominal trauma and the laparoscopic experience varied amongst the operating surgeons, but who believe in the value of laparoscopy in selected cases of abdominal trauma.

\section{Conclusion}

Laparoscopy in abdominal trauma is safe and useful with the appropriate selection of patients by an experienced operating team. It has the advantage of a clear diagnosis in patients with equivocal imaging, reduces the unnecessary laparotomies, hospital stay and complications.

\section{Author's Contributions}

A.E.N. designed the study and wrote the 
manuscript. A.E.N.,M.C. analysed the data. M.C., A.K. and R.V. collected the study data. All authors revised the manuscript and approved the final version.

\section{Conflict of Interest}

None declared.

\section{References}

1. Ball CG, Karmali S, Rajani RR. Laparoscopy in trauma: An evolution in progress. Injury. 2009;40(1):7-10.1.

2. Agresta F, Ansaloni L, Baiocchi GL, Bergamini C, Campanile FC, Carlucci M, et al. Laparoscopic approach to acute abdomen from the Consensus Development Conference of the Società Italiana $\mathrm{d}$ Chirurgia Endoscopica e nuove tecnologie (SICE), Associazione Chirurghi Ospedalieri Italiani (ACOI), Società Italiana di Chirurgia (SIC), Società Italiana di Chirurgia d'Urgenza e del Trauma (SICUT), Società Italiana di Chirurgia nell'Ospedalità Privata (SICOP), and the European Association for Endoscopic Surgery (EAES). Surg Endosc. 2012;26(8):2134-64.

3. Uranues S, Popa DE, Diaconescu B, Schrittwieser R. Laparoscopy in penetrating abdominal trauma. World J Surg. 2015; 39(6):1381-8.

4. Zafar SN, Onwugbufor MT, Hughes K, Greene WR, Cornwell EE 3rd, et al. Laparoscopic surgery for trauma: the realm of therapeutic management. Am J Surg. 2015;209(4):627-32

5. Justin V, Fingerhut A, Uranues S. Laparoscopy in Blunt Abdominal Trauma: for Whom? When? and Why? Curr Trauma Rep. 2017; 3(1):43-50.

6. Nicolau AE, Tutuianu R, Veste V, Merlan V, Negru M, Florescu R, et al. Small bowel perforation caused by compound pelvic fracture found in diagnostic laparoscopy. Chirurgia (Bucur). 2006;101(4):423-8.

7. Smith RS, Fry WR, Morabito DJ, Koehler RH, Organ $\mathrm{CH} J \mathrm{Jr}$ Therapeutic laparoscopy in trauma. Am J Surg. 1995;170(6):632-68.

8. Nicolau AE. Is laparoscopy still needed in blunt abdominal trauma? Chirurgia (Bucur). 2011;106(1):59-66

9. Johnson JJ, Garwe T, Raines AR, Thurman JB, Carter S, Bender JS et al. The use of laparoscopy in the diagnosis and treatment of blunt and penetrating abdominal injuries: 10-year experience at a level 1 trauma center. Am J Surg. 2013;205(3):317-20; discussion 321.

10. Demetriades D, Velmahos G. Technology-driven triage of abdominal trauma: the emerging era of nonoperative management. Annu Rev Med. 2003;54:1-15.

11. Haan J, Kole K, Brunetti A, Kramer M, Scalea TM. Nontherapeutic laparotomies revisited. Am Surg. 2003;69(7):562-5.

12. Schnüriger $B$, Lam $L$, Inaba $K$, Kobayashi $L$, Barbarino $R$, Demetriades D. Negative laparotomy in trauma: are we getting better? Am Surg. 2012;78(11):1219-23.

13. Groven S, Gaarder C, Eken T, Skaga NO, Naess PA. Abdominal injuries in a major Scandinavian trauma center - performance assessment over an 8 year period. J Trauma Manag Outcomes. 2014;8:9.

14. Lee PC, Lo C, Wu JM, Lin KL, Lin HF, Ko WJ. Laparoscopy decreases the laparotomy rate in hemodynamically stable patients with blunt abdominal trauma. Surg Innov. 2014;21(2):155-65.

15. Teixeira PG, Inaba K, Salim A, Rhee P, Brown C, Browder T, et al. Preventable morbidity at a mature trauma center. Arch Surg. 2009:144(6):536-41; discussion 541-2.

16. Hardcastle TC. Missed injury - decreasing morbidity and mortality: a literature review. S Afr J Surg. 2011;49(4):199-201.

17. O'Malley E, Boyle E, O'Callaghan A, Coffey JC, Walsh SR. Role of laparoscopy in penetrating abdominal trauma: a systematic review. World J Surg. 2013;37(1):113-22.

18. Villavicencio RT, Aucar JA: Analysis of laparoscopy in trauma. J Am Coll Surg 1999;189(1):11-20.

19. Hajibandeh S, Hajibandeh S, Gumber AO, Wong CS. Laparoscopy versus laparotomy for the management of penetrating abdominal trauma: A systematic review and meta-analysis. Int J Surg. 2016; 34:127-136.

20. Kawahara NT, Alster C, Fujimura I, Poggetti RS, Birolini D. Standard examination system for laparoscopy in penetrating abdominal trauma. J Trauma. 2009;67(3):589-95.

21. Koto MZ, Matsevych OY, Motilall SR. The Role of Laparoscopy in Penetrating Abdominal Trauma: Our Initial Experience. J Laparoendosc Adv Surg Tech A. 2015;25(9):730-6.

22. Stawicki SP. Trends in nonoperative management of traumatic injuries - A synopsis. Int J Crit IIIn Inj Sci. 2017;7(1):38-57.

23. Bates DD, Wasserman M, Malek A, Gorantla V, Anderson SW, Soto JA et al. Multidetector CT of Surgically Proven Blunt Bowel and Mesenteric Injury. Radiographics. 2017;37(2):613-625.

24. Bhagvan S, Turai M, Holden A, Ng A, Civil I. Predicting hollow viscus injury in blunt abdominal trauma with computed tomography. World J Surg. 2013;37(1):123-6.

25. Matsushima K, Mangel PS, Schaefer EW, Frankel HL. Blunt hollow viscus and mesenteric injury: still underrecognized. World J Surg. 2013;37(4):759-65

26. Polat AV, Aydın R, Nural MS, Gul SB, Kamali Polat A, Aslan K. Bowel and mesenteric injury in blunt trauma: diagnostic efficiency and importance of experience in using multidetector computed tomography. Ulus Travma Acil Cerrahi Derg. 2014;20(6):417-22.

27. Mitsuhide K, Junichi S, Atsushi N, Masakazu D, Shinobu H, Tomohisa E, et al. Computed tomographic scanning and selective laparoscopy in the diagnosis of blunt bowel injury: a prospective study. J Trauma. 2005;58(4):696-701; discussion 701-3.

28. Cirocchi R, Birindelli A, Inaba K, Mandrioli M, Piccinini A. Laparoscopy for Trauma and the Changes in its Use From 1990 to 2016: A Current Systematic Review and Meta-Analysis. Surg Laparosc Endosc Percutan Tech. 2017 Sep 14.

29. Khubutiya MSh, Yartsev PA, Guliaev AA, Levitsky VD, Tlibekova MA. Laparoscopy in blunt and penetrating abdominal trauma. Surg Laparosc Endosc Percutan Tech. 2013;23(6):507-12.

30. Chol YB, Lim KS. Therapeutic laparoscopy for abdominal trauma. Surg Endosc. 2003;17(-3):4217.

31. Zantut LF, Ivatury RR, Smith RS, Kawahara NT, Porter JM, Fry WR, et al. Diagnostic and therapeutic laparoscopy for penetrating abdominal trauma: a multicenter experience. J Trauma. 1997; 42(5):825-9; discussion 829-31.

32. Kindel T, Latchana N, Swaroop M, Chaudhry UI, Noria SF, Choron $\mathrm{RL}$, et al. Laparoscopy in trauma: An overview of complications and related topics. Int J Crit IIIn Inj Sci. 2015;5(3):196-205.

33. Chestovich PJ, Browder TD, Morrissey SL, Fraser DR, Ingalls NK, Fildes JJ. Minimally invasive is maximally effective: Diagnostic and therapeutic laparoscopy for penetrating abdominal injuries. J Trauma Acute Care Surg. 2015;78(6):1076-83. 